ISSN 1112-9867

\title{
NUTRIENTS ASSESSMENT OF ANAEROBIC PALM OIL MILL EFFELUENT (AnPOME) AS AN ALTERNATIVE MEDIA FOR MICROALGAE CULTURE
}

\author{
N. Mohd ${ }^{1,3, *}$, M. S. Takriff ${ }^{1,2}$ and S. F. S. Draman ${ }^{3}$ \\ ${ }^{1}$ Faculty of Engineering and Built Environment, Department of Chemical and Process \\ Engineering, Universiti Kebangsaan Malaysia, 43600 UKM Bangi, Selangor, Malaysia \\ ${ }^{2}$ Research Centre of Sustainable Process Technology (CESPRO), Faculty of Engineering and \\ Built Environment, Universiti Kebangsaan Malaysia, 43600 UKM Bangi, Selangor, Malaysia \\ ${ }^{3}$ Faculty of Chemical Engineering, Universiti Teknologi MARA, Bukit Besi Campus, 23200 \\ Bukit Besi, Dungun, Terengganu, Malaysia
}

Published online: 10 November 2017

\begin{abstract}
The main aim of the present study is to investigate the availability of macronutrient and micronutrient in AnPOME. All collected samples were analyzed using $\mathrm{HACH}$ method. The results reveal that the $\mathrm{C} / \mathrm{N}$ and $\mathrm{N} / \mathrm{P}$ ratio of the AnPOME is six times more than the theoretical value. Concentration of micronutrients also shown higher concentration range compared to that of the Bold Basal Medium (BBM). However, the concentration of phosphorus in AnPOME six times lower than nitrogen indicates that phosphorus limitation in AnPOME. Hence, this finding suggested the best microalgae to be grown in AnPOME is mixotrophic or heterotrophic mode. Overall, reuse of AnPOME replacing synthetic growth is highly recommended considering that enough composition of macronutrient and micronutrient in AnPOME and inexpensive alternative to synthetic media.
\end{abstract}

Keywords: microalgae; Anaerobic Palm Oil Mill Effluent (AnPOME); BBM; macronutrient; micronutrient.

Author Correspondence,e-mail: norzi085@tganu.uitm.edu.my

doi: http://dx.doi.org/10.4314/jfas.v9i6s.71 


\section{INTRODUCTION}

Malaysia is the world's second-largest palm oil producer after Indonesia. The average Malaysian crude palm oil production in 2016 was 17.32 million tonnes and is expected to be increased to 19.85 million tonnes in 2017. Therefore, its status as one of the key players within the country's agro-industry is recognized, solidifying itself as the fourth largest contributor to domestic economy growth. Even though palm oil industry is a major source of financial revenue domestically, it is also a major agro-industrial wastewater producer. Various types of waste produced by the palm oil industry such as oil palm trunks (OPT), oil palm fronds (OPF), empty fruit bunches (EFB), palm pressed fibres (PPF), palm shells and palm oil mill effluent (POME). According to [1], among all the waste produced, POME is said to be the most difficult waste to be handled due to high volume generated. For each tonne of crude palm oil (CPO) production necessitate for 5-7.5 tonnes of water, which $50 \%$ of them converted to POME [2]. Additionally, POME also contains high organic content (COD 50,000 mg/L, BOD 25,000 mg/L), Nitrogen, Phosphate, Potassium, Magnesium and Calcium which can cause eutrophication phenomenon [3]. Therefore, efficient treatment of POME is necessary in order to encourage sustainability of palm oil industry as promoted by the Malaysian Palm Oil Board (MPOB) and the Malaysian Palm Oil Council (MPOC) [4].

Most of the microalgae industry uses commercial media as a culture medium. In order to increase the production rate, supplementary nutrients and fertilizers such as NPK are added during algae cultivation. However, this method has led to the increases of operational costs and occasionally surpass its biomass production profit [5]. Thus, this makes commercial media less suitable for the mass production of microalgae. Alternatively, application of POME as a culture medium provides lower operational cost and beneficial for both industries in a long term. A large-scale outdoor cultivation can be carried out as there are abundant of nutrient sources in POME. Besides, this microalgae cultivation treatment able to overcome the limitation of conventional effluent treatment [6] practiced by most of the palm oil miller. Currently, zero waste technology is introduced to the Malaysian palm oil industry with the aim of no pollutant go to air, land and water. This technology comprises of EPB biomass pretreatmet for biohydrogen production, biohydrogen fermentation and biomethane production from POME and pretreated EFB, heterogeneous catalysis for biomethane 
reforming, biohydrogen purification for steam and power generation, membrane treatment for water recycling and reuse, and bioconversion of EFB agrowaste into organic fertilizers. Cultivation of microalgae through $\mathrm{CO}_{2}$ sequestration also implemented. This will prevent the emission of greenhouse gas (GHG) to the atmosphere. Finally, to ensure the success of zero waste technology, the anaerobic POME (AnPOME) resulting from POME fermentation is reused for algae cultivation. Therefore, the characteristic of AnPOME is important before it can be used as a growth medium of algae. This is because nutrient concentrations are the main factors that need to be addressed to ensure that algae growth is at a maximum level. Hence, the purpose of this study is to identify the macronutrient and micronutrient content of an AnPOME sample taken from various sampling times.

\section{METHODOLOGY}

\subsection{Sampling Site and Collection}

The AnPOME were collected from the anaerobic digester tank from Sime Darby Tenammaram Palm Oil Mill, Bestari Jaya, Selangor, Malaysia GPS location at latitude $3^{\circ} 23^{\prime} 44.30^{\prime \prime} \mathrm{N}$ longitude $101^{\circ} 25^{\prime} 03.41^{\prime \prime}$. Samples collected is stored in closed containers and directly transported to the laboratory without any delay. All samples were kept in a cold room at temperature less than $4^{\circ} \mathrm{C}$, but over the freezing point in order to prevent the wastewater from undergoing biodegradation due to microbial activity [7].

\subsection{AnPOME Characteristics}

AnPOME sample was pre-treated by centrifuged at $8000 \mathrm{rpm}$ for 10 minutes. Afterward, supernatant of the sample was collected and filtered using syringe filter $(0.45 \mu \mathrm{m})$ to remove the solids and kept for further analysis. Hach DR 2800 spectrophotometer has been used for analysis of $\mathrm{COD}, \mathrm{BOD}_{5}, \mathrm{TN}, \mathrm{NH}_{4}{ }^{+}-\mathrm{N}$ and $\mathrm{TP}$ by using Hach reagents accordingly. Whereas, the analysis of turbidity was measured by the Hach 2100 AN Turbidimeter and pH was determined by Cyberscan pH 300m (Eutech Instrument). For total suspended solid (TSS), AnPOME are filtered through Whatman glass microfibers (Grade GF/C $1.2 \mu \mathrm{m}$ ). The filters are dried and weighed to determine the amount of total suspended solids in $\mathrm{mg} \mathrm{L}^{-1}$ of sample. The determination of micronutrient content is performed using Agilent 7700 inductively coupled plasma mass spectrometry (ICP-MS). 


\section{RESULTS AND DISCUSSION}

The properties of pre-treated anaerobic digestive POME (AnPOME) analysed and summarized in Table 1. Results obtained in this study were compared with literature and standard media (BBM). As shown in Table 1, $\mathrm{pH}$ value of this study is 7.82 almost the same as the study conducted by other researchers as well as the $\mathrm{pH}$ of standard media (BBM). The initial $\mathrm{pH}$ of the media is an important for the growth of microalgae [8]. In general, as observed from prior studies, initial $\mathrm{pH}$ of the media affects the solubility and the presence of the carbon dioxide which ultimately controls the growth of the cells [8-9]. The optimum $\mathrm{pH}$ most of the microalgae is between 7 and 8 while $\mathrm{pH}$ lower than 5 or higher than 9 are not tolerable [11]. Thus, the present finding support [11] study which concluded that AnPOME is suitable media for microalgae culture and offers an inexpensive alternative to synthetic media. Total suspended solid (TSS) concentration in the study was $343.33 \mathrm{mg} \mathrm{L}^{-1}$ lower than the regulatory limit of $400 \mathrm{mg} \mathrm{L}^{-1}$. While, the concentration of COD and BOD were $4066.67 \mathrm{mg}$ $\mathrm{L}^{-1}$ and $1146 \mathrm{mg} \mathrm{L}^{-1}$ respectively. These values exceed the regulatory limit of $20 \mathrm{mg} \mathrm{L}^{-1} \mathrm{BOD}$ discharge. Thus, this indirectly implies AnPOME needs to be treated before releasing into the body of water. Besides, the large different characteristics of COD and BOD of AnPOME in this study with [12-13] may cause by many factors. As stated by [14], the characteristics of waste produced by palm oil mill is mainly affected by different oil extraction techniques, quality of oil palm fruit, cropping season and efficiency of wastewater treatment plant.

Theoretically, molecular formula of an average algae cell is $\mathrm{C}_{106} \mathrm{H}_{263} \mathrm{O}_{110} \mathrm{~N}_{16} \mathrm{P}$ which consist of carbon, nitrogen and phosphorus as the main elements. Thus, these macronutrients need to be supplied to the maximum level for the optimum and productive growth. Nevertheless, the unbalanced nutrients inhibit growth of microalgae. In this study, the $\mathrm{C} / \mathrm{N}$ ratio of the AnPOME is six times more than the theoretical value. N/P ratio also shows the same trend. Besides concentrations of nitrogen in AnPOME is $330 \mathrm{mg} \mathrm{L}^{-1}$, significantly higher than in BBM. Meanwhile concentration of phosphorus is similar to BBM. In [15] stated $1 \mathrm{~g}$ of ammoniacal nitrogen or nitrate nitrogen consumption yielded approximately $15.8 \mathrm{~g}$ of microalgae biomass. In another study, Woertz et al proposed a moderate concentration of nitrogen $\left(30 \mathrm{mg} \mathrm{L}^{-1}\right)$ effectively increase the growth rate and lipid production of microalgae [16]. Thus, it is apparent from this study that AnPOME able to provide enough carbon and 
nitrogen sources for microalgae growth.

In addition, another essential macronutrient required by microalgae is phosphorus. It plays major roles in multiple biological functions that involves energy metabolism. For example, association of ATP (adenosine triphosphate) with phosphorus, nucleic acids metabolism (DNA and RNA), maintenance of cell membrane structure (phospholipids) and cell signalling (phosphoprotein) [17]. During phosphorus deficiency in growth media, rate of respiration will be reduced. Consequently, the rate of photosynthesis $\mathrm{CO}_{2}$ decreases while darker $\mathrm{CO}_{2}$ fixation will increase and thereby increase the activity of two enzyme phosphoenolpyruvate carboxylase and phosphoenolpyruvate phosphatase [11]. This study shows that the concentration of phosphorus six times lower than nitrogen indicate that phosphorus limitation in AnPOME. Hence, these findings suggest that in general the best microalgae to be grown in AnPOME is mixotrophic or heterotrophic mode.

Table 1. Characteristics of AnPOME compared to literature and BBM

\begin{tabular}{|c|c|c|c|c|c|}
\hline Parameter & $\begin{array}{l}\text { AnPOME } \\
\text { (This study) }\end{array}$ & {$[18]$} & [12] & [13] & BBM \\
\hline $\mathrm{pH}$ & $7.80 \pm 0.02$ & 7.10 & 7.40 & 7.24 & 7.00 \\
\hline $\mathrm{BOD}\left(\mathrm{mg} \mathrm{L}^{-1}\right)$ & $1146.00 \pm 44.72$ & 1520.00 & 1355.00 & 1938.00 & - \\
\hline $\mathrm{COD}\left(\mathrm{mg} \mathrm{L}^{-1}\right)$ & $4066.67 \pm 136.63$ & 3040.00 & $13,650.00$ & $20,314.00$ & - \\
\hline Turbidity (NTU) & $257.17 \pm 18.21$ & - & - & - & - \\
\hline $\mathrm{NH}_{4}{ }^{+}-\mathrm{N}\left(\mathrm{mg} \mathrm{L}^{-1}\right)$ & $117.83 \pm 5.67$ & - & - & 32.00 & - \\
\hline $\mathrm{TSS}\left(\mathrm{mg} \mathrm{L}^{-1}\right)$ & $343.33 \pm 85.24$ & 334.00 & $12,750.00$ & $14,686.00$ & - \\
\hline $\begin{array}{l}\text { Total Phosphorus, } \\
\left.\qquad \text { TP (mg L }{ }^{-1}\right)\end{array}$ & $57.52 \pm 10.13$ & - & - & 164.00 & 53.35 \\
\hline $\begin{array}{c}\text { Total Nitrogen, TN } \\
\left(\mathrm{mg} \mathrm{L}^{-1}\right)\end{array}$ & $330.00 \pm 30.00$ & 320.00 & 320.00 & - & 41.16 \\
\hline
\end{tabular}

The distribution of micronutrients in AnPOME and BBM is shown in Table 2. It can be seen that concentration of $\mathrm{Na}, \mathrm{Ca}, \mathrm{Mg}$ and $\mathrm{K}$ were approximately $350 \mathrm{mg} \mathrm{L}^{-1}, 25.40 \mathrm{mg} \mathrm{L}^{-1}, 374.08$ $\mathrm{mg} \mathrm{L}^{-1}$ and $2436.43 \mathrm{mg} \mathrm{L}^{-1}$ respectively are in the high ranges compared to that of the BBM. The results also show that, concentration of sodium lower than potassium. Sodium and potassium plays an important role in the transition of molecular nitrogen into ammonia during 
the nitrogen fixing process in microalgae cell [19]. Since sodium and potassium categorized in the same group of the Periodic Table thus it has same chemical properties. Indeed, sodium ion can replace potassium during deficient conditions. The present findings also indicate concentration of magnesium is fifteen times more than calcium. The result is in the lines of earlier literature [20] that found the minimal requirements of magnesium of microalgae reported always to be more than that for calcium. The deficiency of magnesium nutrients in the media will inhibit cell division, resultant in unusually large etiolated cells [20].

Table 2. Distribution of micronutrients in AnPOME and BBM

\begin{tabular}{ccc}
\hline Elements & AnPOME & BBM \\
\hline $\mathrm{Na}$ & $350.00 \pm 12.52$ & 77.46 \\
$\mathrm{Ca}$ & $25.40 \pm 3.48$ & 6.80 \\
$\mathrm{Mg}$ & $374.08 \pm 8.33$ & 10.47 \\
$\mathrm{~K}$ & $2436.43 \pm 44.87$ & 105.50 \\
$\mathrm{Fe}$ & $2.35 \pm 0.91$ & 1.01 \\
$\mathrm{~B}$ & $0.97 \pm 0.08$ & 2.00 \\
$\mathrm{Zn}$ & $1.00 \pm 0.65$ & 2.00 \\
$\mathrm{Mn}$ & $1.56 \pm 0.26$ & 0.40 \\
$\mathrm{Cu}$ & $0.42 \pm 0.02$ & 0.40 \\
$\mathrm{Co}$ & $0.01 \pm 0.00$ & 0.10 \\
\hline
\end{tabular}

*Concentrations of each element are in units of $\mathrm{mg} \mathrm{L}^{-1}$

Moreover, Table 2 indicates that concentration of $\mathrm{Fe}, \mathrm{B}, \mathrm{Zn}, \mathrm{Mn}, \mathrm{Cu}$ and $\mathrm{Co}$ are in the similar level with that in BBM. As reported from previous studied inorganic elements such as $\mathrm{N}, \mathrm{P}, \mathrm{K}$, $\mathrm{Mg}, \mathrm{Ca}, \mathrm{S}, \mathrm{Fe}, \mathrm{Cu}, \mathrm{Mn}, \mathrm{Zn}, \mathrm{Mo}, \mathrm{Na}, \mathrm{Co}, \mathrm{V}, \mathrm{Si}, \mathrm{Se}, \mathrm{Cr}, \mathrm{Cd}, \mathrm{Cl}, \mathrm{B}$ and I found in microalgae. Of these, N, P, Mg, Fe, Cu, Mn, Zn and Mo were essential micronutrients for all microalgae [21]. The roles of each of the micronutrients shown in Table 3. 
Table 3. Role of micronutrients in microalgae cell

\begin{tabular}{cl}
\hline Elements & \multicolumn{1}{c}{ Functions } \\
\hline $\mathrm{Mg}$ & Central atom of chlorophyll molecule, aggregation of ribosomes into function \\
& units, for formation of catalyzed. \\
$\mathrm{Fe}$ & Used in physiological processes such electron transfer reaction in plant \\
& photosynthesis and nitrogen assimilation, respiration, protein and nucleic acid \\
& synthesis. \\
$\mathrm{Cu} \quad$ Electron transport (photosynthesis and respiration) enzymes, disproportionation \\
& of $\mathrm{O}_{2}$ radicals to $\mathrm{O}_{2}$ and $\mathrm{H}_{2} \mathrm{O}_{2}$ in reaction. \\
$\mathrm{Mn}$ & Electron transport in PSII, maintenance of chloroplast membrane structure, \\
& breakdown reactions and those involving halogens. \\
$\mathrm{Zn}$ & Important as a metabolic function in enzymes, element in ribosome structure, \\
& nucleic acid replication and polymerization, hydration and dehydration of $\mathrm{CO}_{2}$.
\end{tabular}

This study has found that generally concentration of micronutrients in AnPOME is sufficient to be used as a source of nutrient for microalgae growth.

\section{CONCLUSION}

In this study, the aim was to assess amount of macronutrients and micronutrients in AnPOME. Overall, the results indicate that compositions of both nutrients in AnPOME were greater or equal than its amount in synthetic media. Therefore, it is proven AnPOME contain adequate macronutrient and micronutrient source for culturing microalgae. Besides, zero waste sustainability concept also can be applied since all waste, including AnPOME from the palm oil production can be reused. The second major finding was that the concentration of phosphorus in AnPOME six times lower than nitrogen resulting slow rate of respiration, increase darker $\mathrm{CO}_{2}$ fixation and reduce photosynthetic $\mathrm{CO}_{2}$ fixation. Significantly, the most suitable microalgae to be cultured in AnPOME were mixotrophic or heterotrophic types. 


\section{ACKNOWLEDGEMENTS}

The authors would like to acknowledge Sime Darby Research Sdn. Bhd. and Universiti Kebangsaan Malaysia for funding the research work under grant number KK-2014-015 and DIP-2016-030, respectively. One of the authors (Norzila Mohd) gratefully acknowledge Universiti Teknologi MARA for the CBBPTB for her study leave.

\section{REFERENCES}

[1] Madaki Y S, Seng L. Palm oil mill effluent (POME) from Malaysia palm oil mills: Waste or resource. International Journal of Science, Environment and Technology, 2013, 2(6):1138-1155

[2] Ahmad A L, Ismail S, Bhatia S. Water recycling from palm oil mill effluent (POME) using membrane technology. Desalination, 2003, 157(1-3):87-95

[3] Adela B N, Muzzammil N, Loh S K, Choo Y M. Characteristics of palm oil mill effluent (POME) in an anaerobic biogas digester. Asian Journal of Microbiology, Biotechnology and Environmental Sciences Paper, 2014, 16(1):225-231

[4] Hariz H B, Takriff M S. Palm oil mill effluent treatment and $\mathrm{CO}_{2}$ sequestration by using microalgae-Sustainable strategies for environmental protection. Environmental Science and Pollution Research, 2017, 24(25): 20209-20240

[5] Ferrell J, Sarisky-Reed V. National algal biofuels technology roadmap. EERE Publication and Product Library, 2010

[6] Khaldi H, Maatoug M, Dube C S, Ncube M, Tandlich R, Heilmeier H, Laubscher R K, Dellal A. Efficiency of wastewater treatment by a mixture of sludge and microalgae. Journal of Fundamental and Applied Sciences, 2017, 9(3):1454-1472

[7] Eaton A D, Clesceri L S, Rice E W, Greenberg A E, Franson M A. APHA: Standard methods for the examination of water and wastewater. Washington DC: American Public Health Association (APHA), 2005

[8] Zhan J, Rong J, Wang Q. Mixotrophic cultivation, a preferable microalgae cultivation mode for biomass/bioenergy production, and bioremediation, advances and prospect. International Journal of Hydrogen Energy, 2017, 42(12):8505-8517

[9] Azov Y. Effect of $\mathrm{pH}$ on inorganic carbon uptake in algal cultures. Applied and 
Environmental Microbiology, 1982, 43(6):1300-1306

[10] Osterlind S. Growth of a planktonic green alga at various carbonic acid and hydrogen-ion concentrations. Nature, 1947, 159(4032):199-200

[11] Ghosh A, Khanra S, Mondal M, Halder G, Tiwari O N, Bhowmick T K, Gayen K. Effect of macronutrient supplements on growth and biochemical compositions in photoautotrophic cultivation of isolated Asterarcys sp.(BTA9034). Energy Conversion and Management, 2017, 149:39-51

[12] Chan Y J, Chong M F, Law C L. Biological treatment of anaerobically digested palm oil mill effluent (POME) using a Lab-Scale Sequencing Batch Reactor (SBR). Journal of Environmental Management, 2010, 91(8):1738-1746

[13] Phang S M, Kim-Chong O. Algal biomass production in digested palm oil mill effluent. Biological Wastes, 1988, 25(3):177-191

[14] Wu T Y, Mohammad A W, Jahim J M, Anuar N. Pollution control technologies for the treatment of palm oil mill effluent (POME) through end-of-pipe processes. Journal of Environmental Management, 2010, 91(7):1467-1490

[15] Dalrymple O K, Halfhide T, Udom I, Gilles B, Wolan J, Zhang Q, Ergas S. Wastewater use in algae production for generation of renewable resources: A review and preliminary results. Aquatic Biosystems, 2013, 9(1):1-11

[16] Woertz I, Feffer A, Lundquist T, Nelson Y. Algae grown on dairy and municipal wastewater for simultaneous nutrient removal and lipid production for biofuel feedstock. Journal of Environmental Engineering, 2009, 135(11):1115-1122

[17] Corbridge D. E. Phosphorus: Chemistry, biochemistry and technology. Florida: CRC Press, 2013

[18] Husna A T, Luqman C A, Azni I, Thomas S Y C. Effluent quality of anaerobic palm oil mill effluent (POME) wastewater using organic coagulant. International Journal of Science and Research, 2015, 4(5):667-677

[19] Ahmad A, Buang A, Bhat A H. Renewable and sustainable bioenergy production from microalgal co-cultivation with palm oil mill effluent (POME): A review. Renewable and Sustainable Energy Reviews, 2016, 65:214-234

[20] Becker E. W. Microalgae: Biotechnology and microbiology. England: Cambridge 
University Press, 1994

[21] Borowitzka M. A., Beardall J., Raven J. A. The Physiology of microalgae. Cham: Springer International Publishing, 2016

\section{How to cite this article:}

Mohd N, Takriff M S, Draman S F S. Nutrients assessment of anaerobic palm oil mill effeluent (anpome) as an alternative media for microalgae culture. J. Fundam. Appl. Sci., 2017, 9(6S), 981-990. 